\title{
Soft Tissue Sarcoma Pathologic Primary Tumor TNM Finding v7
}

National Cancer Institute

\section{Source}

National Cancer Institute. Soft Tissue Sarcoma Pathologic Primary Tumor TNM Finding v7. NCI Thesaurus. Code C88451.

A pathologic finding about one or more characteristics of soft tissue sarcoma, following the rules of the TNM AJCC V7 classification system as they pertain to staging of the primary tumor. 